\title{
Analysis of Factors That Influence The Delay in Reporting The Realization of Village Funds in New Villages in Rote Ndao Regency
}

\author{
Deni R. S. Zacharias ${ }^{1}$, I Komang Arthana ${ }^{2}$, Sarinah Joyce. M Rafael ${ }^{3}$ \\ \{denyzacharias82@gmail.com ${ }^{1}$, fenkqajuz@gmail.com ${ }^{2}$, sjoyce.rafael@gmail.com ${ }^{3}$ \} \\ Nusa Cendana University, Indonesia, Jalan Adi Sucipto Penfui 85001, Kupang, Nusa Tenggara Timur, \\ Indonesia ${ }^{1,2,3}$
}

\begin{abstract}
The timely reporting of the realization of village funds has a huge influence on the smooth distribution of village funds. However, there are often delays in reporting the realization of village funds caused by several factors, namely human resources, facilities and infrastructure, geographical location, reporting standards and government internal control systems. The study was conducted to find out how the influence of each factor on the occurrence of delays in reporting the realization of village funds. This research is quantitative descriptive. Data collection through questionnaire distribution. The data analysis technique used is descriptive statistics, validity test, reliability test and hypothesis test. The results of the study show that human resources, infrastructure, geographical location, reporting standards and the government's internal control system influence the occurrence of delays in reporting the realization of village funds.
\end{abstract}

Keywords: late reporting, village funds.

\section{Introduction}

Village funds are funds sourced from the State Revenue and Expenditure Budget (APBN) intended for villages that are transferred through the district/city APBN and are used to finance government administration, implementation of development, community development, and community empowerment (Ministry of Finance, 2017). The village fund program has been started since 2015 until now with an increase in the amount of funds each year. Stages of village fund management include planning, implementation, administration, reporting to accountability. Changes in the procedures for managing village funds continue to be carried out by the government to improve the efficiency of village fund programs. In 2018 the procedures for managing village funds refer to PMK No.225 / PMK 07/2017. The most difficult stage to be implemented in managing village funds is the reporting stage. Timeliness of Submission Report of Responsibility for Realization The implementation of the Village Revenue and Expenditure Budget (APBDes) has a huge influence on the smooth distribution of village funds where the report is used as a condition in disbursing village funds the following year. The instrument of timeliness is the availability of report information, systematic and regular reports (Government Accounting Standards, 2010).

Based on data obtained from the Ministry of Village, village funds provided by the central government to NTT Province from 2015 to 2018 continue to increase. In 2015 as the initial year for the entry of village funds, the province of NTT received village funds in the amount of Rp. Furthermore, in 2016 it increased by $131 \%$ to Rp1,889,353,802,000. 2017 increased by $28 \%$ to Rp. 2,360,353,320,000. And in 2018 it increased by $7.5 \%$ to Rp. 2,537,837,576,000. Village funds that have been received by NTT Province are then channeled to the 21 existing districts. Rote Ndao Regency is one of the districts in NTT that receives a large amount of village funds, with a total of 10 sub-districts consisting of 82 old villages and 30 newly created villages that received village funds for the first time in 2018.

Based on data from the Ministry of Home Affairs (MOHA) In 2015 village funds allocated to Rote Ndao Regency amounted to Rp23,228,248,000. Then in 2016, village funds in Rote Ndao District increased by $124 \%$ to Rp. 5,2124,542,000. In 2017, the amount of village funds increased by $28 \%$ to Rp. 
66,765,336,000. And in 2018, the amount of village funds increased by $38 \%$ to Rp. $92,287,919,000$. PMK Number 225 / PMK.07 / 2017, article 1 paragraph 5 concerning changes in reporting procedures, states that the village head submits a report on the realization of the implementation of the Village Revenue and Expenditure Budget (APBDes) which also contains realization of village funds to the district at each stage of distribution. The first phase of the report is the report on the realization of the absorption and achievement of village fund output in the previous fiscal year delivered no later than the beginning of March of the current fiscal year. While the report on the realization of absorption and achievement of village fund output up to stage II must be submitted no later than July of the current budget year.

Submission of reports on the realization of village funds in Rote Ndao District always has a long delay from the time it should be (Rote online news, 2018). Rote Ndao Regency has 30 newly created villages that received village funds in 2018. This is because these 30 villages are only definitive in 2017 (Regulations of Regent Rote Ndao Number 30 of 2017). As a beginner recipient of village funds, these villages experienced delays in delivering village funds realization. Phase I and II reporting should be carried out no later than the beginning of June of the current year, but in reality the villages carry out reporting in mid-August to early September. This will cause disbursement of village funds for the next stage will also experience delays that affect the increasingly late village development (DPMD of Rote Ndao District, 2018). The problems in this study were formulated as follows: Are human resources, facilities and infrastructure, geographical location and reporting standards and the government's internal control system can affect the delay in reporting the realization of village funds in new villages in Rote Ndao district. While the objectives to be achieved from this study are to find out the influence of HR, Infrastructure, Geographical Location, Reporting Standards and SPIP on the delay in reporting the realization of village funds in new villages in the Rote Ndao District area.

\section{Literature Review and Hypothesis Development \\ 2.1 Village Formation and Village Scope}

Villages are legal community units that have territorial limits that are authorized to regulate and manage government affairs, the interests of the local community based on community initiatives, origin rights, and / or traditional rights recognized and respected in the system of government of the Unitary Republic of Indonesia (Law No. 6 Year 2014).

The formation of the village is one form of village structuring activities carried out by the government, the provincial government, and the district / city government. Formation of villages can be in the form of expansion from one village to two or more villages, merging village sections from villages that are side by side into one village, or merging several villages into one new village (Law No.6 of 2014).

\subsection{Village Fund}

According to PP No. 60 of 2014 concerning Village Funds sourced from the APBN, Village Funds are funds originating from the State Budget intended for Villages that are transferred through the district / city APBN and used to finance government administration, implementation of development, community development, and community empowerment. The amount of the budget allocation that is allocated directly to the village is determined to be $10 \%$ outside the regional transfer funds in stages. Budgets sourced from the APBN are calculated based on the number of villages and allocated by taking into account the population, poverty rate, area size, and level of geographical difficulties in order to improve welfare and equitable distribution of village development. The population, area, and poverty rate are calculated by weight: (1). $30 \%$ for the total population of districts / cities; (2). $20 \%$ for district / city area; and (3). $50 \%$ for district / city poverty rates.

\subsection{Village Financial Management}

Village financial management starting from the planning, implementation, reporting and accountability phases is guided by the Minister of Home Affairs Regulation Number 20 of 2018 concerning Village Financial Management which is described as follows: Village Financial Planning. 1). Implementation of Village Finance; 2). Village Finance Administration; 3). Reporting; and 4). Village Financial Accountability. 


\subsection{Village Fund Realization Report}

According to Murtiono and Wulandari (2014), the report on the realization of village funds is a form of accountability from village management holders to provide information about village activities and activities to the village government community for village fund management and implementation in the form of program plans funded by village funds. Regarding the reporting mechanism for the use of village funds, it is clearly stipulated in PMK No.225 / PMK.07 / 2017, namely: (1) The village head submits a report on the realization of the use of village funds at each stage to the regent / mayor.

The realization report on the use of village funds consists of: a). Report on the use of village funds in the previous fiscal year, which is submitted no later than the second week of March of the current budget year; and b). Report on realization of use of village funds stages I and II, submitted no later than the second week of July of the current budget year.

The regent / mayor can facilitate the acceleration of submitting reports on the realization of the use of village funds. The regent / mayor submits a report on the realization of the distribution and consolidation of the use of village funds to the Minister of Director General of Financial Balance with a copy to the Governor, Minister of Home Affairs, Minister of Village, Development of Disadvantaged Regions and Transmigration, which consists of: a). Report on the realization of the distribution and consolidation of the use of the Village Fund in the previous fiscal year; and b). Report on the realization of distribution and consolidation of the use of Village Funds stages I and II.

\subsection{Factors Affecting Delays in Reporting on Realization of Village Funds}

Human Resources elements or in this case are village officials, as follows (Santoso, 2016): a). Capacity of Village Officials; b). Autonomous Village Officials; and c). Development of Village Apparatus. The elements in the facilities and their relation to village fund reporting are as follows (Setiawan, 2017): a). Device is a complete support for the facilities available in the village to support the preparation of reports on the realization of village funds. Three indicators to measure the complete range of devices, namely the presence of hardware such as the availability of electricity and computers, funds for the procurement of devices and the availability and utilization of internet network systems; and b). Management of Financial Data. It is an illustration that shows the use of technology and infrastructure to compile reports on the realization of village funds. Three indicators in financial data management are guidelines for utilizing technology facilities, utilization of applications in accordance with needs and computerized accounting processes.

Care is an indicator that shows the schedule of maintenance and data collection of scheduled equipment to support the process of preparing reports on the realization of village funds. Geographical aspects such as location, distance and accessibility are aspects that greatly affect the timeliness of submitting reports on the realization of village funds (Wida, 2016). The location of the village is closely related to the natural conditions and topography in the village. Topography describes the physical characteristics of the earth. The same is true of the relationship with the village, such as the location of the village directly adjacent to hills, sea, river or mountain. Village distance from the sub-district and district government centers is also an indicator of geographical location because, if the distance between the village and the central government district is approximately $30 \mathrm{Km}$, reporting of the realization of village funds will be too late. This also applies if the distance between villages and districts reaches approximately $40 \mathrm{~km}$. Accessibility is the degree of ease achieved by people, towards an object, service or environment. The ease of access is implemented in buildings, the environment, public roads, transportation and other public facilities. Accessibility is an indicator of geographical location because the availability of public transportation facilities and public road conditions are very influential in reporting the realization of village funds.

Reporting Standardsor village funds there are 2 elements in the reporting standard for village funds, namely: a). Reporting Mechanism in PMK No. 225 / PMK.07 / 2017; b). PMK No. 225 / PMK.07 / 2017 concerning Village Financial Management describes the format of village financial reports which include reports on the realization of village funds along with provisions in village financial management; and c). District and District Reporting Standards. Village financial reports differ from public sector and government financial reports. Village financial reports are also simple. There are no 
provisions that regulate the format of reports on the realization of village funds that must be submitted by the village to the sub-district and district governments. This has caused village officials to have no reference in compiling reports on the realization of village funds (BPKP, 2015).

Government Internal Control System (SPIP). The government internal control system (SPIP) is a system of internal control that is carried out thoroughly in the central government and regional government. Control environment means that the heads of government agencies are required to create and maintain a control environment that creates positive behavior and is conducive to the implementation of internal control systems in their work environment. The heads of government agencies are required to carry out risk assessments. Risk assessment consists of: a). Risk identification. Implemented an adequate mechanism to recognize risks from external factors and internal factors; and b). Risk analysis. Implemented to determine the impact of risks that have been identified towards achieving the objectives of government agencies.

The head of a government agency must carry out control activities in accordance with the size, complexity and nature of the duties and functions of the relevant government agency. Control activities consist of: (1) review of the performance of the tangible government agencies, (2) fostering human resources, (3) control over management of information systems, (4) physical control of assets, (5) separation of functions, (6) authorization of important transactions and events, (7) accurate and timely recording of transactions and events, (8) good documentation of internal control systems and important transactions and events.

To carry out effective communication, leaders of government agencies must at least: (a) provide and take advantage of various forms and means of communication and (b) manage, develop and update information systems continuously. Supervision of the internal control system is carried out through continuous supervision, separate evaluations, and follow-up on audit recommendations and other reviews.

\subsection{Delays in Reporting on Village Funds}

Financial statements must be presented on time so that they can be used as a basis for economic, social, political and political decision making and to avoid delays in making such decisions. Constraints on the timeliness of presenting reports are related to the length of time required by the organization to produce financial statements. The faster the presentation of financial statements, the better for decision making. The problem is that the more information needs, the more time it will take to produce such information. Financial reports may be presented in a timely manner so that they are not relevant for decision making (Mardiasmo, 2009).

The instrument of timeliness is the availability of systematic and regular report information, reports (SAP, 2010). Timeliness in submitting work unit level financial reports (SKPD) relates to several factors, both in the preparation process and conveying it. These factors include educational background, training, availability of facilities, and understanding of regulations. The village government in financial reporting should be able to provide timely information and be free from misleading understanding (Susanti and Wardani, 2017).

\subsection{Effect of Human Resources on Delays in Reporting on Realization of Village Funds}

The results of the research by Widyatama, Novita, and Diarespati (2017) show that HR competency has no significant effect on ADD allocation, whereas Azhari's research results (2018) show that human resources are a factor that influences the delay in reporting village funds because of the relative level of human resource competency low, and research Rabb (2016), shows that human resources are a factor that influences the management of ADD, and Widowati, Santoso (2016), human resources are factors that influence the management of ADD, because the level of competency of human resources is relatively low. This is indicated by a low level of education and a lack of training, mentoring and socialization for officials who manage village funds. Based on the description above, a hypothesis can be obtained, namely:

H1: HR affects the reporting of realization of village funds

\subsection{Effect of Facilities and Infrastructures on Delays in Reporting on Realization of Village Funds}

The results of Azhari's research (2018) state that facilities and infrastructure are one of the important things in supporting the management of village funds. The availability of complete facilities 
and infrastructure without training as well as guidebooks to be used as a reference is also an obstacle in preparing village fund realias reports to be delivered in a timely manner. The results of Widowati's research, Santoso (2016) also show that office facilities and infrastructure are the main unaccountable indicators of village fund management. Based on the description above, a hypothesis can be obtained, namely:

$\mathrm{H} 2$ : Facilities and infrastructure affect the delay in reporting the realization of village funds.

\subsection{Effect of Geographical Position on Delays in Reporting on Village Funds}

Geographical aspects such as location, distance and accessibility are aspects that greatly affect the timeliness of submitting reports on the realization of village funds (Wida, 2016). The results of Azhari's research (2018) show that the geographical location of the village is also a factor that affects the delay in reporting the realization of village funds. Things like the location of the village office are relatively not in the center of the village and the distance between the village office and the district office is very much influential on the period of submission of the report on the realization of village funds. Based on the description above, a hypothesis can be obtained, namely:

H3: Geographical position affects the reporting of realization of village funds

\subsection{Effect of Reporting Standards on Delays in Reporting on Realization of Village Funds}

The results of Azhari's research (2018) state that reporting standards are things that also affect the delay of village officials in compiling and submitting reports on the realization of village funds. This is due to the absence of standard standards set by the sub-district and district governments to become a reference for village officials in preparing reports on the realization of village funds. the lack of socialization of regulations in the preparation of village fund reports made village officials misunderstand the actual deadline for submitting reports on the realization of village funds. Based on the description above, a hypothesis can be obtained, namely:

H4: Standard reporting standards have an effect on reporting the realization of village funds

\subsection{Effect of the Government's Internal Control System on Delays in Realization of Reporting on Realization of Village Funds}

The results of the Widyatama, Novita, and Diarespati (2017) studies show that the Apparatus Control System of the Village Government significantly influences the Village Fund's Location Financial Management Accountability (ADD). Based on the description above, a hypothesis can be obtained, namely:

H5: SPIP affects the reporting of realization of village funds

\section{Research Methods}

The research approach used by researchers is a quantitative approach. Quantitative approach is a research approach that views a reality that can be classified, concrete, observable and measurable, the relationship of variables is causal where the research data is in the form of numbers and the analysis uses statistics (Sugiyono, 2017).

Data was obtained from respondents by distributing questionnaires to parties who were competent and understood the management and reporting of the realization of the use of village funds in new villages in Rote Ndao District.

The population of this study was all village officials in 30 new villages / pemekaran in the area of Rote Ndao Regency. The researcher used a purposive technique to determine the sample. The criteria used are as follows: (1). Village officials in villages with the highest number of villagers. Because the population is an object as well as the subject of village development and (2). Village officials who deal directly with village fund reporting. Namely the village head, village secretary, village treasurer, and head of development affairs in the villages that are the object of research.

The number of respondents in this study were 4 respondents from each village $X$ the number of villages chosen for sampling $(16)=64$. The data analysis technique uses the SPSS version 25 application to determine the validity test, reliability test, hypothesis test. 


\section{Results and Discussion}

Rote Ndao Regency is a part of the East Nusa Tenggara Province which is located on anIndonesian hidden veranda with the capital of this district located in Ba'a. This district has an area of 1,280.10 km2. Rote Ndao Regency is located in 1025 '- 1100' South Latitude and 12149 '- 12326' East Longitude. Rote Ndao Regency consists of 82 old villages and 30 new villages which are spread over 10 sub-districts, namely Landu Leko, Lobalain, Ndao Nuse, Rote Timur, Pantai Baru, Rote Tengah, Rote Selatan, Rote Barat Daya, Rote Barat Laut, and Rote West.

Table 1. Descriptive Statistics

\begin{tabular}{ccccccc}
\hline Variabel & N & Minimum & Maximum & Sum & Mean & $\begin{array}{c}\text { Std. } \\
\text { Deviation }\end{array}$ \\
\hline Total_X1 & 64 & 12 & 23 & 1092 & 17.06 & 2.690 \\
Total_X2 & 64 & 14 & 23 & 1103 & 17.23 & 1.743 \\
Total_X3 & 64 & 11 & 18 & 919 & 14.36 & 1.597 \\
Total_X4 & 64 & 14 & 22 & 1099 & 17.17 & 1.714 \\
Total_X5 & 64 & 12 & 18 & 916 & 14.31 & 1.446 \\
Total_Y & 64 & 11 & 18 & 885 & 13.83 & 1.686 \\
\hline
\end{tabular}

The lowest value of the HR variable is 12 while the highest value is 23 . The average value of the $\mathrm{HR}$ variable is 17.06 and the standard devision is 2.690. The lowest value of the facilities and infrastructure variable is 14 , while the highest value is 23 . The average value of the facilities and infrastructure variable is 17.23 and the deviation standard is 1.743 . The lowest value of the geographical location variable is 11 , while the highest value is 18 . The average value of the geographical location variable is 14.36 and the standard deviation is 1.597 . The lowest value of the standard reporting variable is 14 , while the highest value is 22 . The average value of the standard reporting variable is 17.17 and the standard deviation is 1.714. For the lowest SPIP variable the value is 12 , while the highest value is 18 . The average value of the SPIP variable is 14.31 and the standard deviation is 1.446 . The lowest value for the delay in reporting the realization of village funds is 11 , while the highest value is 18 . The average value of the variable delay in reporting the realization of village funds is 13.83 and the standard devision of 1.686 .

Table 2. The Result of Multiple Regression Analysis

\begin{tabular}{c|c}
\hline Variable & $\begin{array}{c}\text { Regression } \\
\text { Coefficient }\end{array}$ \\
\hline Konstanta & $-2,600$ \\
SDM & 0,118 \\
Sarana \\
prasarana \\
Letak \\
$\begin{array}{c}\text { geografis } \\
\text { Standar } \\
\text { pelaporan } \\
\text { SPIP }\end{array}$ \\
\hline
\end{tabular}

\subsection{Results of Multiple Regression Analysis}

The table shows a constant value of $-2,600$ which means it shows the amount of reporting delay of $-2.6 \%$ when there are no HR variables, infrastructure, geographical location, reporting standards and SPIP. HR suitability variables provide a coefficient of 0.118 , infrastructure facilities provide a coefficient value of 0.190 , geographical location variables provide a coefficient value of 0.257 , reporting standard variables provide a coefficient value of -0.178 and SPIP variables provide a coefficient of 0.307 . 
Table 3. Partial Test Result

\begin{tabular}{c|c|c}
\hline Model & T & Sig. \\
\hline SDM & 2,540 & 0,014 \\
Sarana Prasarana & 2,214 & 0,031 \\
Letak Geografis & 2,339 & 0,023 \\
Standar Pelaporan & 2,228 & 0,030 \\
SPIP & 2,871 & 0,006 \\
\hline
\end{tabular}

\subsection{Effect of Human Resources on Delays in Reporting on Realization of Village Funds}

The partial test results in Table 4.22, show the value of the HR variable t count of 2.540 and at the level of the possibility of a 5\% error, and the significance value of the HR variable of 0.014 . SDM has a tcount of 2.540>t table 2.002 and a significance value of $0.014<0.05$. Based on the results of these calculations, it was concluded that HR had a positive and significant effect on the delay in reporting the realization of village funds.

\subsection{Effect of Facilities and Infrastructure on Delays in Reporting on Realization of Village Funds}

The partial test results in Table 4.22, show the value of the variable facilities and infrastructure amounting to 2,214 and at the level of possibility of a 5\% error, and the significance value of the facilities and infrastructure variable is 0,031 . Facilities and infrastructure have a value of tcount 2.214> t table 2.002 and a significance value of $0.031<0.05$. Based on the results of these calculations, it was concluded that infrastructure had a positive and significant effect on the delay in reporting the realization of village funds.

\subsection{Effect of Geographical Position on Delays in Reporting on Realization of Village Funds}

The partial test results in Table 4.22, show the tcount value of the geographical location of 2,339 and at the level of possibility of a 5\% error, and the significance value of the facilities and infrastructure variable is 0,023 . Geographical location has a value of tcount 2.333>t table 2.002 and a significance value of $0.023<0.05$. Based on the results of these calculations, it can be concluded that the geographical location variables have a positive and significant effect on the delay in reporting the realization of village funds.

\subsection{Effect of Reporting Standards on Delays in Reporting on Realization of Village Funds}

The partial test results in Table 4.22, show the value of the t reporting standard variable of 2.282 and at the level of possibility of a $5 \%$ error, and the significance value of facilities and infrastructure variable is 0.030 . The reporting standard has a value of $\mathrm{t} 2228>\mathrm{t}$ table 2.002 and a significance value of $0.030<0.05$. Based on the results of these calculations, it can be concluded that the standard reporting variable has a positive and significant effect on the delay in reporting the realization of village funds.

\subsection{Effect of SPIP on Delays in Reporting on Realization of Village Funds}

The partial test results in Table 4.22, show the value of the SPIP variable of 2.871 and at the level of the possibility of a $5 \%$ error, and the significance value of the SPIP variable of 0.006 . SPIP has a tcount of 2.871> t table 2.002 and a significance value of $0.006<0.05$. Based on the results of these calculations, it was concluded that SPIP had a positive and significant effect on the delay in reporting the realization of village funds.

Table 4. Determination Coefficient Test

\begin{tabular}{|c|c|c|c|c|c|}
\hline Model & R & & R Square & Adjusted R Square & $\begin{array}{c}\text { Std. Error of the } \\
\text { Estimate }\end{array}$ \\
\hline 1 & $.911^{\mathrm{a}}$ & & 0,830 & 0,816 & 0,724 \\
\hline
\end{tabular}

The value of $\mathrm{R}$ Square shows the influence of the independent variables of HR, Infrastructure facilities, Geographic location, reporting standards and SPIP on the dependent variable, the delay in reporting the realization of village funds. The testing of determination coefficient obtained Adjusted $\mathrm{R}$ Square value of 0.816 , this means that the influence of independent variables on the dependent variable is $82 \%$. While $18 \%$ are influenced by other factors. Other factors include internal factors, namely the 
gender manager reporting the realization of village funds. From external factors, namely political conditions such as the change of regional head and the capabilities of the local inspectorate.

Gender is a consensus belief about the differences in male and female characteristics that show different behaviors in acting. In the work environment when a problem occurs, the behavior of female employees tends to avoid the consequences of conflict, although in many situations women do more work than men. While the behavior of male employees in conflict situations feels challenged to deal with it rather than avoid it (Taufik, 2014). Substitution of regional heads (political conditions), namely where if elected new regional leaders, tend to investigate regional financial problems in order to reveal hidden issues in the financial statements, and will recruit auditors to resolve them. This anticipation is feared to extend the preparation period for village financial reporting (Cohen and Leventis, 2013). Capability of the inspectorate is the ability to carry out supervisory tasks consisting of capability, authority and HR competencies that the auditor must have in carrying out supervision. The capability of the inspectorate is higher, so it will affect the level of regional financial supervision including village finance. (Taufik, 2014).

Based on the results of data analysis that has been done, it can be further elaborated as follows:

\subsection{Effect of Human Resources on The Delay in Reporting The Realization of Village Funds}

The results of testing the first hypothesis show that human resources have a positive and significant effect on the delay in reporting the realization of village funds. Human resources are something that is very important and must be owned in an effort to achieve the goals of the organization or company. Human resources are the main elements of the organization compared to other resource elements such as capital and technology, because humans themselves control other factors. The same goes for villages and village fund management which also requires adequate, ready and competent human resources in managing village funds. The problem that arises in implementing village fund management is the lack of human resources (HR) who are ready to manage village funds. HR competency is one of the important points in implementing the Village Fund.

Elements of competency in Human Resources or in this case are village officials consisting of the capacity of village officials, village officials tupoksi village development funds. The capacity of village officials is a standardization of the capacity of village officials, both in terms of quality and quantity. The capacity of village officials in new villages in Rote Ndao Regency in terms of education level indicators still has officers who are graduating from junior high school. This certainly contradicts the PERMENDAGRI No.83 of 2015 concerning the Appointment and Dismissal of Village Devices. In Article 2 paragraph (1) it is stated, Village Devices are appointed by the Village Head of the Village residents who have met the General and Special Requirements. Where the general requirements of the first item are written: "Education is at the lowest for a high school or equivalent". After being traced by conducting interviews, respondents stated that the level of education in the village where they worked was indeed quite low. This is due to a lack of prior public understanding of the importance of education. So that it has an impact on the lack of village officials who have the last high school education or equivalent. The low level of education of the authorities will also.

\subsection{Affect The Ability of Village Officials to Prepare Reports on The Realization of Village Funds}

Autonomy of the village includes the division of tasks and understanding of village officials on the tasks they have. Village officials in the new villages in Rote Ndao District already have a good separation of functions and duties, but do not yet have good abilities to carry out their duties and functions properly. From the results of interviews with researchers and respondents, it was also known that there was already a separation of duties of good village officials within the village. Then for HR development indicators, the apparatus of new villages in Rote Ndao District have received accounting and training training in preparing reports on the realization of village funds, but from the interviews it is known that village officials still need guidance to prepare reports on the realization of village funds.

The results of this study are supported by Azhari's research (2018), namely that human resources influence the delay in reporting the realization of village funds. Widowati and Santoso (2016), namely human resources affect the management of village funds.

\subsection{Effect of Facilities and Infrastructure on Delays in Reporting The Realization of Village Funds}


The results of testing the second hypothesis show that facilities and infrastructure have a positive and significant effect on the delay in reporting the realization of village funds. This is in accordance with the hypothesis proposed previously which states that facilities and infrastructure affect the delay in reporting the realization of village funds. From the frequency of the questionnaire's answers, it was found that the facilities and infrastructure in the new villages in Rote Ndao District were on average inadequate. The factor is the status of a new village / bloom so that supporting facilities for reporting village funds are still incomplete. Not all new villages have village office buildings, village offices temporarily operate at the village head's house or other village officials. Electronic equipment such as computers are available but are still limited, but reporting on the realization of village funds in all new villages has been computerized. The village government has also prepared a special budget to procure operational support resources to assist village officials in preparing reports on the realization of village funds. Whereas for software in this case, internet and WiFi networks are not yet available in every new village in Rote Ndao Regency, this causes the process of sending data and information relating to the report on realization of village funds to be too late.

New villages in Rote Ndao District have not yet set a maintenance schedule for village infrastructure. From the results of interviews, it is known that village officials do not yet know the importance of the maintenance schedule for infrastructure. Viewed in terms of utilization of infrastructure facilities have not been utilized properly. From the observations of researchers in the field, there were a number of village offices whose facilities and infrastructure were not used and were only stored, this was due to the lack of knowledge of the use of these facilities.

There are also uses of facilities such as computers that are not as they should be. From the results of interviews with several respondents, it is known that there are village officials who use facilities and infrastructure for personal gain. The results of this study are consistent with the research of Widowati and Santoso (2016) which shows that office facilities and infrastructure are one of the obstacles that are not accountable for managing village funds.

\subsection{Effect of Geographical Location on The Delay in Reporting The Realization of Village Funds}

The results of the third hypothesis testing show that the geographical location has a positive and significant effect on the delay in reporting the realization of village funds. Geographical location is a position where the region is based on its shape and location on earth. In relation to the report on the realization of village funds, the geographical location is also a factor that can affect the delay in reporting the realization of village funds. In this study, the geographical location was measured by 2 indicators, namely the village office location and distance. This study shows that the majority of village office locations in new villages in Rote Ndao District are not in the center of the village. This caused the location of the village office to be a little difficult to reach. Furthermore, relating to the location of the village is the natural boundary between the new village and the neighboring village in the area of Rote Ndao District. New villages in Rote Ndao Regency have natural borders with neighboring villages. Based on the results of direct observation in the field, the majority of the natural boundaries in the new villages in Rote Ndao Regency are hills and sea boundaries.

In this study, geographical location is also related to distance. The focus of this research is the distance between the village office where the village officials work to the sub-district office and the distance between the village office to the district office. This is because in carrying out the reporting of the realization of village funds, village officials must conduct verification at the sub-district office and then bring the report on the realization of village funds to the district office. The results of the study show that the distance between the offices of the new villages and the subdistrict office reaches $20 \mathrm{Km}$. And for the distance between the village office and the district office to reach $40 \mathrm{Km}$. This shows that the distance from almost every village office in the new villages to the Rote Ndao district office reaches approximately $40 \mathrm{~km}$.

It can be concluded that the distance to the district office is relatively far away, so that village officials have a relatively long time to reach the district office which increases the level of delay in reporting the realization of village funds. This can be overcome by using the internet network in the village to send data and information on the realization of village funds reports.

The results of this study are consistent with Wida's (2016) research, namely geographical aspects such as location, distance and accessibility are aspects that greatly influence the timeliness of submitting 
reports on the realization of village funds, and Azhari's research (2018) that the geographical location affects the delay in submitting village funds realization reports.

\subsection{Effect of Reporting Standards on Delays in Reporting The Realization of Village Funds}

The results of testing the fourth hypothesis show that reporting standards have a positive and significant effect on reporting the realization of village funds. The manager of reporting on the realization of village funds in new villages in Rote Ndao District has worked in accordance with the guidelines / reporting stages of PMK No. 225 / PMK.07 / 2017. From the interviews, it is known that the managers of reporting on the realization of village funds have understood the reporting stages according to PMK No. 225 / PMK.07 / 2017. To get further information related to this point, the researcher gave further questions about the time of submitting the report on the realization of village funds. The majority of respondents stated that they were on time, namely the submission of the report on the realization of village funds for the first and second stages carried out in September of the current year and for the third stage of the end of the year carried out in March of the following year. However, as is known in Part Four Article 25 paragraph (2a) states that the report on the realization of village funds, the previous fiscal year is submitted no later than the second week of February of the following year. Whereas paragraph (2b) states that reports on realization of village funds in stages I and II, are submitted no later than the second week of July of the current year.

In addition, there are already reporting standards from districts and sub-districts that are implemented in the village. However, the results of the research show that the managers of reporting on the realization of village funds have not understood the reporting standards well. This is an obstacle to the reporting stage of the realization of village funds. The district government also has not given special attention such as socialization and training regarding the system and procedures for reporting the realization of village funds. To overcome this problem, it is necessary to have regular training and socialization from the government regarding the stages and standards of reporting to village officials tasked with preparing reports on the realization of village funds.

The results of this study are consistent with Azhari's research (2018) which states that reporting standards are things that also affect the delay of village officials in compiling and submitting reports on the realization of village funds.

\subsection{The Influence of The Village Government's Internal Control System on The Delay in Reporting The Realization of Village Funds}

The results of the fifth hypothesis testing show that the government control system has a positive and significant effect on reporting the realization of village funds. The purpose of the government's internal control system according to PP No. 60 of 2008 is to provide adequate assurance about; effective and efficient activities, reliable financial reports, safeguarding state assets and compliance with legislation. Elements of the government's internal control system, namely the control environment, risk assessment, control activities, information and communication and internal control monitoring.

Discipline rules for village officials and clear responsibilities, performance reviews of village officials and the process of supervision, inspection and evaluation support the effectiveness of village government internal controls in managing village funds. In this case the village head must have a plan to reduce the risk of violations of the system and during the procedure for reporting the realization of village funds. In addition, to support the effectiveness of village government internal controls, the village head must also review the performance of the manager of the village fund realization report with the target expected by the village government. The information system within the village is also one of the important indicators of a good village government internal control system, where the information system must be updated regularly.

Based on the description, it can be concluded that the better the internal control system of the village government, the less likely the delay in reporting the realization of village funds in new villages in Rote Ndao District. The results of this hypothesis testing are supported by the results of the Widyatama, Novita, and Diarespati (2017) studies showing that the Apparatus Control System of the Village Government significantly influences the Village Fund's Location Financial Management Accountability (ADD). 


\section{Conclusions and Recommendations}

Based on the formulation of the problem, objectives, theoretical basis, hypothesis, and the results of tests conducted, it can be concluded that the variables of human resources, facilities and infrastructure, geographical location, reporting standards, and the village internal control system significantly influence the delay in reporting the realization of village funds. This means that with low human resource capabilities in managing the reporting of realization of village funds, incomplete infrastructure, the geographical location of villages that are not strategic, poorly understood reporting standards and poor village government internal control systems, reporting on the realization of village funds is increasingly late.

Based on the results of the research described in the conclusions obtained, the suggestions that can be given are: (1) To District and District Governments in terms of overcoming human resource problems so that they conduct training and assistance more often to village officials especially in preparing reports on realization of village funds. Basic computer training is more often done and gives village officials written guidelines so that village officials are not confused when experiencing obstacles in utilizing operational facilities to prepare reports on the realization of village funds. In terms of overcoming the problem of geographical location, the government should pay more attention to the condition of the internet network in the area of new villages in Rote Ndao District. Installation of WiFi that can be used for sending information relating to reports on the realization of village funds.

The reporting standards from the District and District governments are regularly socialized and can be a solution to overcome the problem of lack of understanding of village officials in preparing reports on the realization of village funds in a timely manner. It is necessary to improve internal control in the village both in the control environment, risk assessment, control activities, village information systems and supervision of the government and village apparatus, (2) Factors that affect the delay in reporting the realization of village funds in this study consist of only 5 variables, namely human resources, facilities and infrastructure, geographical location, reporting standards, and village government internal control systems. It is expected that the next researcher can develop other variables not examined in this study, which might influence the delay in reporting the realization of village funds, both other internal and external factors and (3) research using questionnaires namely sometimes the answers given by respondents do not indicate really is. It is better for future researchers to use the mixed method so that they will get more and more new information, which was not present in this study.

\section{References}

[1]Azhari, D. Y.: Faktor- faktor yang mempengaruhi keterlambatan pelaporan realisasi dana desa di Kecamatan Amabi Oefeto Timur. e-Journal S1 Ak. Universitas Nusa Cendana (2018)

[2]Mardiasmo.: Akuntansi Sektor Publik. Yogyakarta. CV Andi (2009)

[3]Rabb, A. D. A.: Implementasi kebijakan dana desa berdasarkan Peraturan Menteri Keuangan nomor 93 tahun 2015 (studi desa di Kecamatan Ganra, Kabupaten Soppeng). Universitas Islam Negeri Alauddin Makassar (2016)

[4]Republik Indonesia.: BPKP. Pengelolaan keuangan desa. Jakarta (2015)

[5]Republik Indonesia.: Kementrian Keuangan. Buku saku dana desa. Jakarta (2017)

[6]Republik Indonesia.: Undang - Undang No. 06 Tahun 2014 tentang desa. Jakarta (2014)

[7]Republik Indonesia.: Peraturan Pemerintah Nomor 60 Tahun 2008 tentang SPIP. Jakarta (2008)

[8]Republik Indonesia.: Peraturan Pemerintah No. 60 Tahun 2014 tentang dana desa yang bersumber dari APBN. Jakarta (2014)

[9]Republik Indonesia.: Permendagri Nomor 20 Tahun 2018 tentang pengelolaan keuangan desa. Jakarta (2018)

[10]Republik Indonesia.: PMK No. 225/PMK.07/2017 Tentang perubahan kedua PMK No.50 tentang tata cara penyaluran, pengalokasian, penggunaan, pengawasan dan evaluasi dana desa. Jakarta (2017)

[11]Republik Indonesia.: Peraturan Bupati Rote Ndao nomor 30 tahun 2017 tentang pembentukan 30 desa baru. Rote Ndao (2017)

[12]Santoso, E. B.: Pengaruh sistem pengendalian intern pemerintah, pemanfaatan teknologi informasi dan kompetensi sumber daya manusia terhadap akuntabilitas keuangan daerah (studi empiris pada Pemerintah Kabupaten Lampung Timur). Universitas Lampung (2016) 
[13]Setiawan, M. W.: Analisis transparansi dan akuntabilitas pelaporan alokasi dana desa. Vol. 7. eJournal S1 Ak. Universitas Pendidikan Ganesha. (2017)

[14]Sugiyono.: metode penelitian kuantitatif kualitatif, kombinasi dan R\&D. Bandung: Alfabeta (2017)

[15]Wida, S. A., \& Taufik, K.: Akuntabilitas pengelolaan Alokasi Dana Desa (ADD) di desa-desa Kecamatan Rogojampi Kabupaten Banyuwangi. e-Journal Akuntansi Universitas Jember (2016)

[16]Widyatama.: Pengaruh kompetensi dan sistem pengendalian internal terhadap akuntabilitas pemerintah desa dalam mengelola Alokasi Dana Desa (ADD). e-Journal STIE Panca Bhakti Palu (2017) 